\title{
RESEARCH ON EMPLOYMENT RELATIONS
}

\section{Ronald Dore*}

Much of the writing on wages, labour markets, industrial training, work organization and industrial relations in developing countries (the range we attempt to cover by the term 'employment relations') proceeds on assumptions to which the concept of 'market' is fundamental; there is mobility of labour in response to changing demand-supply relations, impersonal relations between employer and employed, 'going rates' for wages for different skills, and union bargaining over such going rates. True, it is generally assumed that 'market imperfections' are even greater than in developed countries, but not so much so as to require a different order of analysis.

Our research starts from the suspicion that this is a pretty irrelevant model, and that something which could best be named an 'organization-oriented model' rather than a 'market-oriented model' would better fit the realities of the situation. Its main features are: a sharp dualism between the 'formal' and 'informal' sectors, and, in the formal sector, a distinction between permanent and temporary workers, very low mobility of permanent workers, their recruitment as young school-leavers into bottom-rung-of-the-ladder entry ports, internal promotion chains, wage differentials fixed with regard to internal job structures and the place of a job on a workers' career trajectory, a good deal of internal training and company welfare provision, and enterprise unions or union branches as the effective bargaining agent over enterprise wage structures.

I came to that suspicion from a comparative study of employment relations in Britain and Japan. It seemed to me that the 'organization-oriented' system of the Japanese was not just due to national character but to a variety of features which made the constraints and conditions of Japan's late development different from Britain's pioneer development - the technological leap when one imports big technology rather than gradually inventing one's own; the

\footnotetext{
* Ronald Dore is a Fellow of the Institute of Development Studies and Director of the M.Phil course in interdisciplinary development studies.
} 
consequent training needs; the import, too, of 'advanced' organizational patterns and theories of human motivation; faster population growth and greater labour surplus; the planning ethos, state direction of in dustrialization and greater stability of prospects for large enterprizes; the development of formal educational systems ahead of industrialization; the need, given ILO etc., influences, to accept the legitimacy of unions and give them a role. From this came the notion of a common 'late-development pattern' which one should expect to find elsewhere.

Whether one does find it or not, and if so whether it appears to be for the reasons suggested, was the point of our research. The three countries, Senegal, Mexico, Sri Lanka, were chosen to be as different as possible in two other dimensions which one would expect largely to affect the pattern of employment relations - the nature of the pre-industrial social structure and the nature of the metropolitan colonial influence -- as well as in the maturity of their industrialization; the 'Iateness' of their late development. Susantha Goonatilake, Maureen Mackin tosh and Miguel Sanchez Padron did most of the field research and the SSRC financed it.

1 For a fuller development of these ideas see R.P. Dore, British Factory - Japanese Factory: the origins of national diversity in industrial relations, 1973, and, more briefly, R.P. Dore, 'The Labour Market and Patterns of Employment in the Wage Sector of LDCs: Implications for the Volume of Employment Generated', World Development vol.2 no. 4 \& 5, April/May 1974, pp. 1-7. 